\title{
PENGEMBANGAN MEDIA PUZZLE UNTUK MENUMBUHKAN KEMAMPUAN MENGENAL HURUF LATIN BAGI ANAK USIA DINI
}

\author{
Suci Amalia \\ Jurusan Pendidikan Islam Anak Usia Dini \\ Fakultas Tarbiyah dan Keguruan UIN Alauddin Makassar \\ Kampus II JL. H. M. Yasin Limpo No. 36 Samata-Gowa, Sulawesi Selatan, \\ Telepon: 085777453199 \\ E-mail: suciamalia118@gmail.com \\ Dahlia Patiung \\ Jurusan Pendidikan Islam Anak Usia Dini \\ Fakultas Tarbiyah dan Keguruan UIN Alauddin Makassar \\ Kampus II JL. H. M. Yasin Limpo No. 36 Samata-Gowa, Sulawesi Selatan, \\ Telepon: 081241755965 \\ E-mail: dahliapatiung@yahoo.co.id
}

\begin{abstract}
Abstrak
Penelitian ini bertujuan untuk mengetahui media puzzle untuk menumbuhkan kemampuan mengenal huruf latin anak usia dini. Penelitian ini adalah penelitian pengembangan sampai uji tahap validasi dengan mengembangkan sebuah produk yang sudah ada sebelumya dengan menggunakan model pengembangan ADDEI, Analysis, Design, Develop, Evaluation, dan Implementation). Jenis penelitian yang digunakan yaitu penelitian pengembangan atau Research and Development/ $R \& D$. Teknik pengumpulan data menggunakan lembar validasi, adapun instrument penelitiannya yaitu lembar validasi dan dokumentasi, sedangkan teknik analisis data menggunakan analisis data pengembangan dan analisis data kevalidan. Hasil penelitian menunjukkan bahwa media puzzle huruf latin setelah dikembangkan dan divalidasi oleh ahli validator media dapat dikatakan sangat valid dan dapat digunakan sebagai media pembelajaran huruf latin untuk anak usia dini, slain itu dapat memudahkan pendidik dalam proses belajar mengajar. Dari hasil analisis data kevalidan media dan instrument, diperoleh nilai rata-rata kevalidan dari semua validator $3,52 \leq V \leq 4$ sangat valid sehingga dapat dikatakan media puzzle huruf latin dapat meningkatkan kemampuan anak dalam mengenal huruf. Peningkatan ini terjadi karena kelengkapan fitur media puzzle huruf latin berupa tema yang beragam, ilustrasi yang menarik dari segi gambar, nama gambar, huruf a-z, warna, bentuk, dan segi penggunaannya.
\end{abstract}

Kata Kunci: Anak Usia Dini; Huruf Latin; Pengembangan Media Puzzle

\section{Abstract}

This study aims to validate the puzzle media that can enhance early childhood recognize Latin letters. The study was development research as it developed the previous media with the ADDIE development model. The data collected with 
validation sheets and documentation as the instruments. The collected data then analyzed for the development process and validation. The finding showed that the developed Latin alphabet puzzle media was very valid. It indicates the media can use in learning Latin letters in early childhood. It also can facilitate the educators in the teaching and learning process. In other words, since the average value of the validity of all validators was $3.52 \mathrm{~V} \leq 4$, it means very valid. It appears that the media can improve children's ability to recognize letters. The medium has various themes, attractive image illustrations, image names, letters a-z, colors, shapes, and easy to use.

Keywords: Early Childhood; Latin Letters; Puzzle Media Development

\section{PENDAHULUAN}

Pendidikan adalah kebutuhan langsung dan harus terus dipenuhi sepanjang hidup, tanpa adanya pendidikan sangatlah mustahil bagi sekumpulan orang untuk hidup dan berkreasi sesuai dengan keinginan atau tujuan untuk terus maju, berkembang, dan hidup bahagia yang ditunjukkan dengan gagasan menurut konsep hidup manusia (Cahyono, 2015). Pendidikan diarahkan untuk membantu pertumbuhan dan perkembangan baik itu jasmani maupun rohani, melalui pendididikan anak diharapkan memiliki kesiapan dalam memasuki pendidikan lebih lanjut. Pendidikan anak usia dini (PAUD) diarahkan untuk memfasilitasi tumbuh kembang anak secara sehat dan optimal sesuai dengan nilai, norma, dan harapan masyarakat. Pendidikan tersebut dilakukan melalui pemberian pengalaman dan rangsangan yang kaya dan maksimal. Oleh karena itu, diperlukan lingkungan yang kondusif bagi pertumbuhan dan perkembangan anak. (Latif, Mukhtar. Zulkhairina, Rita Zubaidah, 2016).

Hasil observasi awal yang dilakukan peneliti di PAUD AL-Ikhlas Sumpang Bita, Kec. Balocci, Kab. Pangkep, Rabu 18 September 2019. sebagian peserta didik di Sekolah PAUD, peneliti menemukan bahwa masih ada beberapa peserta didik yang belum mampu mengenal huruf dengan baik. Hal ini ditandai dengan saat anak diminta untuk menyebutkan huruf, mereka masih bingung dalam hal itu. Terutama kesulitan dalam membedakan huruf yang hampir mirip seperti huruf a dengan o, huruf $p$ dengan $q, M$ dengan $W, v$ dengan $f$, dimana seharusnya pada usia 4-5 tahun, anak sudah bisa mengenal huruf dengan baik. Menurut (Trisniwati, 2014) kemampuan mengenal huruf adalah kemampuan anak dalam mengetahui atau mengenal dan memahami tanda-tanda aksara dalam tata tulis yang merupakan huruf-huruf abjad dalam melambangkan bunyi, bentuk, dan tulisan. Kemampuan anak dalam mengenal huruf merupakan pengetahuan yang dapat dilihat dari kemampuan anak dalam menyebutkan simbol huruf a sampai z dengan benar, selain itu anak dapat memahami huruf sehingga anak mampu menyebutkan huruf dari sebuah kata dengan benar yang merupakan anggota abjad yang melambangkan bunyi Bahasa menurut (Rahayuningsih, Sheila Septiana. Tritjahjo Danny Soesilo, 2019) Oleh karena itu peneliti tertarik untuk menggunakan media puzzle huruf latin. 
Salah satu Guru PAUD AL-Ikhlas Sumpang Bita, Kec. Balocci, Kab. Pangkep, NJ menyampaikan bahwa mengenal huruf sulit bagi anak karena harus menguasai tiga aspek belajar huruf, yaitu mengenal bentuk tulisan, mengenal huruf, dan mengenal bunyi. Disisi lain terdapat kendala dalam ketersediaan media sebagai sumber belajar untuk mengenal huruf. Stimulasi pada anak dalam mengembangkan kemampuan mengenal huruf latin belum dilakukan secara maksimal. Oleh karena itu diperlukan media pembelajaran yang dapat membantu anak usia dini dalam proses pembelajaran huruf latin.

Berdasarkan permasalahan tersebut peneliti mengembangkan media puzzle huruf latin untuk menumbuhkan kemampuan mengenal huruf latin bagi anak usia dini. Media puzzle menurut (Y. D. M. Sari, 2016) adalah media yang terdiri atas kepingan-kepingan dari satu gambar tertentu yang dapat melatih tingkat konsentrasi dan emosional anak. Media puzzle ini memiliki model penyelesaian dengan cara menyusun potongan-potongn gambar menjadi suatu gambar kesatuan yang utuh. Media puzzle dapat dikatakan media visual yang menarik minat bagi anak untuk belajar. media puzzle merupakan media yang terbuat dari bahan dan bentuk yang bermacam-macam, seperti bahan kayu berbentuk persegi, karbon, plastik yang ringan, gabus berbentuk persegi besar yang menyerupai tikar, dan dapat berbentuk kubus, persegi atau lempengan, dan lain-lain.

Media puzzle terdapat beberapa macam desain, salah satunya adalah media puzzle huruf. media ini terbuat dari huruf-huruf yang terpisah dan dapat disusun kembali menjadi rangkaian kata-kata sesuai dengan puzzle huruf yang digunakan menurut (Y. R. Sari, 2019). Melalui permainan ini, anak dirangsang membuat rangkaian kata dari huruf-huruf yang disediakan dan untuk melatih penguatan memori terhadap huruf. Dalam penggunaan media puzzle huruf dapat merangsang anak untuk berinteraksi dengan huruf dan kata sehingga anak akan menyukai kegiatan membaca. (Madyawati, 2017)

Media puzzle dapat dikatakan media visual yang menarik minat bagi anak untuk belajar menurut (Y. D. M. Sari, 2016) karena melalui media puzzle huruf latin, anak diharapkan dapat menemukan hal baru dalam aspek belajar huruf (mengenal huruf, menulis, menyebutkan atau membedakan huruf) sehingga anak dapat merasa gembira dan tidak merasa bosan. selain itu anak dapat memahami huruf dan anak mampu menyebutkan huruf dari sebuah kata dengan benar (Trisniwati, 2014). Tanpa disadari anak telah belajar mengenal huruf latin dan dapat membantu anak yang masih kurang dalam kemampuan mengenal hurufnya untuk lebih mudah dan cepat memahami. Salah satu media pembelajarannya adalah media puzzle, media ini dapat mempengaruhi aspek perkembangan bahasa pada anak terutama mengenal huruf. (Srimulyanti, 2016).

Menurut Vyigotsky dalam (Marlinda, 2014) mengatakan pada umumnya bahasa dan pikiran anak berbeda. Kemudian secara perlahan, sesuai tahap perkembangan mentalnya, bahasa dan pikirannya menyatu sehingga bahasa 
merupakan ungkapan dari suatu pikiran. Anak secara alami belajar bahasa dari interaksinya dengan orang lain untuk berkomunikasi, yaitu menyatakan pikiran dan keinginan memahami pikiran dan keinginan orang lain. Oleh karena itu, belajar bahasa yang paling efektif ialah dengan bergaul dan berkomunikasi dengan orang lain.

\section{METODE PENELITIAN}

(Sugiyono, 2019) menyatakan jenis penelitian yang digunakan adalah jenis penelitia pengembangan atau $R \& D$ (Research and Development). Richey, and Kelin, dalam Sugiyono menggunakan nama Design and Development Research yang dapat diterjemahkan menjadi perancangan dan penelitian pengembangan. Borg and Gall menyatakan bahwa penelitian pengembangan adalah proses atau metode yang akan digunakan untuk memvalidasi dan mengembangkan suatu produk. Adapun produk yang dimaksud tidak hanya berupa benda seperti buku teks, atau film untuk pembelajaran, tetapi juga metode seperti bahan ajar untuk program pendidikan atau non pendidikan. Adapun model pengembangan menurut (Punaji, 2016) dapat diartikan sebagai suatu proses desain konseptual sebagai upaya dalam meningkatkan fungsi dari model yang telah ada sebelumnya. Terdapat berbagai model desain atau rancangan yang telah dikembangkan dengan mengikuti pola tertentu dan mencakup sejumlah komponen yang saling berkaitan.

Model pengembangan yang digunakan pada penelitian ini adalah model pengembangan berbentuk media untuk bahan pembelajaran anak usia dini, peneliti akan membuat suatu media puzzle huruf bergambar berbentuk persegi dengan lebar kepingan berbentuk gelombang. Teknik pengumpulan data pada penelitian ini adalah dengan menggunakan lembar validasi dan dokumentasi. Teknik analisis data yang akan digunakan pada penelitian ini adalah menganalisis data pengembangan dan menganalisis data kevalidan terhadap produk yang akan dikembangkan.

\section{HASIL DAN PEMBAHASAN}

Hasil penelitian ini menghasilkan sebuah produk berupa media pembelajaran dengan menggunakan model pengembangan ADDIE. Model pengembangan ADDIE model pembelajaran yang terdiri dari lima tahap, yaitu: Menganalisis (Analysis), Perancangan (Design), Pengembangan (Develop), Penilaian (Evaluation), dan Mengimplementasikan (Implementation). Namun peneliti hanya menggunakan tiga tahapan dikarenakan pada saat penyusunan penelitian, kondisi tidak memungkinkan peneliti untuk melakukan dua tahapan yaitu penilaian dan implementasi sehingga media pembelajaran yang akan digunakan pada penelitian ini hanya sampai pada tahap pengembangan (Develop).

Tahap Penelitian ini menurut (Dwi, 2019) sebagai berikut: (1)Menganalisis (Analysis), Proses analysis yang peneliti lakukan yaitu melakukan observasi awal untuk mencari data atau informasi aktual dengan melakukan wawancara terhadap 
guru atau tenaga pendidik anak usia dini. Pada tahapan wawancara peneliti mencari informasi tentang bagaimana kemampuan belajar anak usia dini terkhusus dalam mengenal huruf latin. Setelah informasi didapatkan, peneliti mencari referensi terkait dengan media puzzle huruf latin, yang dimana harapan peneliti dengan adanya media puzzle huruf latin dapat membantu meningkatkan minat belajar anak usia dini. Anlysis merupakan tahap utama dalam penggunaan model pengembangan ADDIE.

Peneliti perlu melakukan proses penilaian kebutuhan. Dalam penilaian kebutuhan yang dimaksud adalah peneliti dapat mengumpulkan data atau informasi yang terkait mengenai produk pembelajaran anak usia dini. Setelah mendapatkan sejumlah data, peneliti dapat merencanakan sebuah produk pembelajaran yang akan dikembangkan dan melakukan rancangan penelitian sampai uji tahap validasi. Oleh karena itu, ada tahap analisis agar peneliti dapat mengetahui kemapuan yang seharusnya dimiliki anak usia dini. Selain itu, analisis dilakukan untuk mengidentifikasi kemampuan yang dimiliki anak usia dini. (2) Perancangan (Design), Design bertujuan untuk menyiapkan suatu rancangan awal sebelum membuat produk media pembelajaran. Adapun proses perencanaan yang terdiri dari tahap penentuan tema, tujuan, pemilihan alat dan bahan, dan membuat instrument penelitian sebelum melakukan pengembangan produk. (3)Tahap pengembangan (Develop), pada tahap ini menghasilkan suatu rancangan media pembelajaran yang telah direvisi berdasarkan masukan dari pakar ahli, tahap ini meliputi validasi media pembelajaran oleh pakar yang kemudian direvisi berdasarkan masukan dari pakar dan dosen pembimbing untuk selanjutnya dilakukan perbaikan hingga menghasilkan media pembelajaran yang sesuai dengan yang diinginkan.

Hasil penelitian pengembangan yang dilakukan oleh (Dinar, 2021) sampai uji tahap validasi dapat dilihat dari penilaian oleh valiator ahli dinyatakan valid dan dapat diuji coba pada skala terbatas di lapangan. Namun pada penelitian ini tidak dapat dilakukan uji coba di lapangan dikarenakan situasi saat ini yang masih pandemi Covid-19 yang mengakibatkan kegiatan belajar mengajar secara langsung di sekolah ditiadakan dan dilakukan secara online, sehingga peneliti tidak dapat melanjutkan penelitian ini sampai pada tahap uji coba lapangan tetapi hanya sampai pada tahap uji validator. Menurut (Mustami, 2017) kategori valid dari suatu perangkat penelitian dan instrument pendukung penelitian minimal berada dalam kategori cukup valid.

Menurut (Putra, 2019) Berdasarkan hasil penelitian pengembangan sebagai metode penelitian yang sistematis, dan bertujuan untuk mencaritemukan kebaruan, keunggulan, merumuskan, dan memperbaiki suatu produk yang sudah ada sebelumnya dengan mengembangnkan atau menghasilkan produk untuk diuji keefektifannya, dengan melihat model, metode/strategi/cara, prosedur tertentu yang lebih unggul, baru, efektif, efisien, produktif, dan bermakna. Pengembangan ini dilakukan sampai uji tahap validasi dengan model pengembangan ADDIE dengan 
lima tahapan (Analysis, Design, Develop, Implement dan Evaluate).

Pengembangan media puzzle huruf telah dijelaskan sebelumnya bahwa pengembangan media pembelajaran puzzle huruf berdasarkan model pengembangan ADDIE yang meliputi tiga tahapan yang telah digunakan pada penelitian ini yaitu menganalisis (analysis), merancang (design), dan pengembangan (development).

Adapun yang di analysis pada penelitian ini adalah awal yang harus dilalui sebelum membuat rancangan media pembelajaran puzzle huruf dengan tujuan untuk mengidentifikasi masalah-masalah yang sering dihadapi oleh pendidik dan peserta didik dalam proses pembelajaran dan perlu mendapatkan perhatian yang sangat serius. Peneliti mengumpulkan informasi dengan melakukan observasi awal. Selain itu, peneliti memperkuat informasi dengan melakukan wawancara kepada Guru PAUD mengenai pembelajaran mengenal huruf anak usia dini. Berdasarkan observasi awal yang dilakukan peneliti, sebagian peserta didik di Sekolah PAUD, peneliti menemukan bahwa masih ada beberapa peserta didik yang belum mampu mengenal huruf dengan baik. Hal ini ditandai dengan saat anak diminta untuk menyebutkan huruf, mereka masih bingung dalam hal itu. Terutama kesulitan dalam membedakan huruf yang hampir mirip seperti huruf a dengan 0 , huruf $p$ dengan $q$, $M$ dengan $W, v$ dengan $f$, dimana seharusnya pada usia 4-5 tahun, anak sudah bisa mengenal huruf dengan baik. Belajar mengenal huruf termasuk dalam perkembangan aspek bahasa, dimana bahasa anak menurut (Khuriah, 2014) adalah bahasa yang dipakai untuk menyampaikan keinginan, pikiran, harapan, permintaan dan lain-lain untuk kepentungan pribadinya. Oleh karena itu peneliti tertarik untuk menggunakan media puzzle huruf latin.

Tahap design peneliti melakukan perancangan desain dilihat dari penentuan tema Puzzle huruf latin, kemudian peneliti membuat perancangan awal media dari segi fisik puzzle huruf latin, dan proses selanjutnya peneliti melihat lagi dari segi manfaat dan penggunaanya berdasarkan dari tema yang diangkat. Kemudian peneliti membuat instrument penelitian melihat dari analisis data, rancangan segi fisik, manfaat, dan penggunaannya yang kemudian divalidasi oleh validator ahli media untuk mengetahui kelayakan produk atau kevalidannya apakah layak untuk dijadikan sebagai media pembelajaran bagi anak usia dini.

Tahap pengembangan (Development), setelah perancangan desain produk peneliti kemudian melakukan tahap pengembangan media dengan memberikan instrument penelitian dan contoh rancangan fisik produk yang telah dibuat dan kemudian dinilai oleh ahli validator media. Setelah divalidasi, dilakukan revisi produk sesuai saran dari validator untuk mengurangi kelemahan yang kemudian akan menghasilkan produk puzzle yang siap dipakai untuk bahan pembelajaran di sekolah.

Tabel 1. Uraian Indikator Penilaian Validator 


\begin{tabular}{|c|c|c|c|}
\hline \multirow{2}{*}{ I } & \multirow{2}{*}{ Rancangan Segi Fisik Puzzle Huruf Latin } & \multicolumn{2}{|c|}{ Penilaian Validator } \\
\hline & & Validator I & Validator II \\
\hline 1. & $\begin{array}{l}\text { Jenis bahan kayu yang akan digunakan yaitu kayu } \\
\text { seru }\end{array}$ & 4 & 4 \\
\hline 2. & Ukuran sisi puzzle huruf $40 \mathrm{~cm} \times 32 \mathrm{~cm}$ & 4 & 4 \\
\hline 3. & Ukuran kepingan puzzle $5 \mathrm{~cm} \times 5 \mathrm{~cm}$ & 3 & 4 \\
\hline 4. & Bentuk kepingan puzzle bergelombang & 3 & 2 \\
\hline 5. & Terdapat huruf latin besar dan kecil a-z & 4 & 3 \\
\hline 6. & $\begin{array}{l}\text { Terdapat macam-macam gambar pada setiap } \\
\text { kepingan puzzle huruf latin }\end{array}$ & 4 & 4 \\
\hline 7. & $\begin{array}{l}\text { Terdapat nama gambar pada setiap kepingan } \\
\text { puzzle huruf latin }\end{array}$ & 4 & 4 \\
\hline 8. & Kesesuaian gambar dengan huruf latin & 4 & 4 \\
\hline 9. & $\begin{array}{l}\text { Terdapat macam-macam warna pada huruf, } \\
\text { gambar, dan nama gambar }\end{array}$ & 4 & 4 \\
\hline 10. & $\begin{array}{l}\text { Jenis puzzle huruf latin jika dilihat dari } \\
\text { kepraktisannya (mudah disimpan dan } \\
\text { dipindahkan) }\end{array}$ & 4 & 4 \\
\hline
\end{tabular}




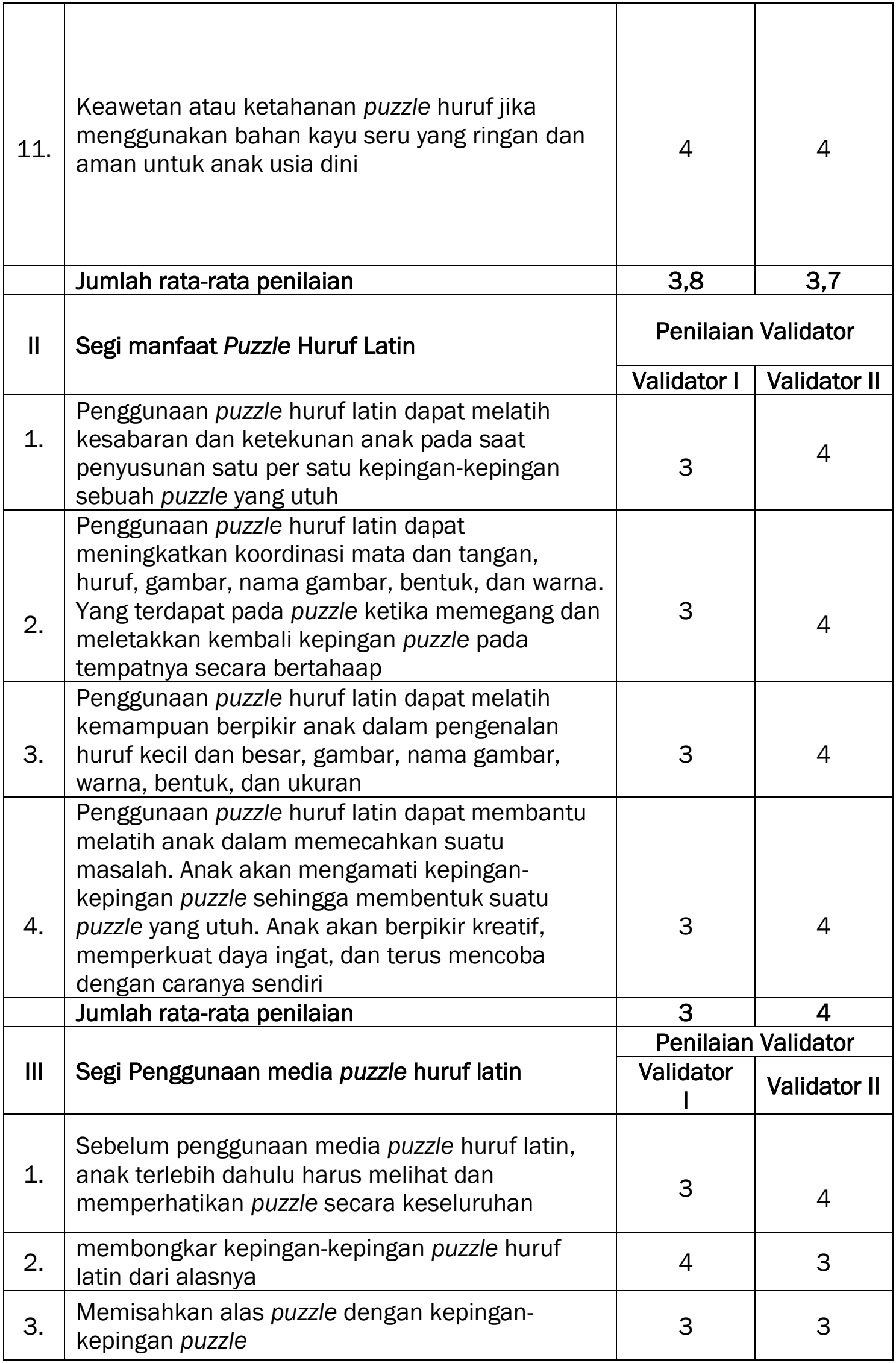




\begin{tabular}{|c|l|c|c|}
\hline 4. & $\begin{array}{l}\text { Aduk dan acak kepingan kepingan-kepingan } \\
\text { puzzle yang telah dibongkar }\end{array}$ & 3 & 3 \\
\hline 5. & $\begin{array}{l}\text { Mengambil satu-persatu kepingan puzzle } \\
\text { kemudian menyusun seperti bentuk semula }\end{array}$ & 4 & 3 \\
\hline 6epingan puzzle dapat disusun secara berurutan & $\begin{array}{l}\text { dimulai a-z dapat juga disusun secara acak } \\
\text { tergantung cara atau kenyamanan anak dalam } \\
\text { menyelesaikan puzzle }\end{array}$ & $\mathbf{3 , 5}$ & $\mathbf{3 , 1}$ \\
\hline & Jumlah rata-rata penilaian & \\
\hline
\end{tabular}

Tabel 2. Rata rata penilaian Vlidator

\begin{tabular}{|l|c|c|}
\hline \multicolumn{1}{|c|}{ Aspek Penilaian } & Hasil Penilaian & Kategori \\
\hline Rancangan Segi Fisik Puzzle Huruf Latin & 3,75 & Sangat Valid \\
\hline Segi Manfaat Puzzle Huruf Latin & 3,5 & Valid \\
\hline Segi Penggunaan Puzzle Huruf Latin & 3,3 & Valid \\
\hline Rata-rata Penilaian & 3,52 & Sangat Valid \\
\hline
\end{tabular}

Dalam pengembangan media puzzle ini peneliti menambahkan gambar dan nama gambar. Berikut contoh desain media setelah pengembangan :

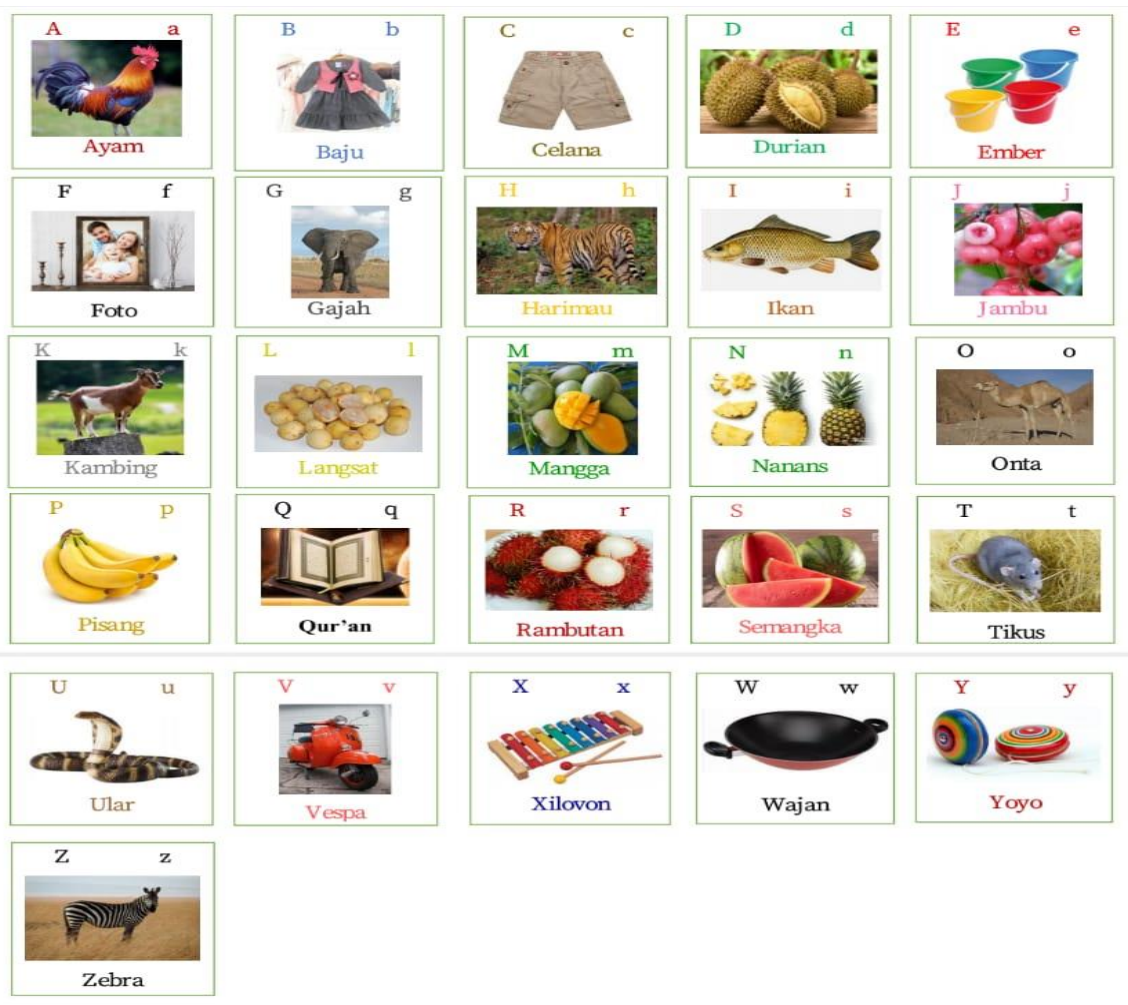

Gambar 1. Hasil Pengembangan Puzzle 
Berdasarkan hasil validator mengenai penilaian rancangan segi fisik puzzle huru latin dari 11 indikaotr tersebut mendapat 4 poin sangat valid dan 2 indikator mendapat poin 3 yaitu valid. Sedangkan berdasarkan penilaian validator dua pada lembar validator terdapat 10 indikator mencapai poin 4 sangat valid, serta 1 indikator mendapat poin 2 yaitu kurang valid.

Adapun alasan validator terhadap pemberian skla penilaian pada rancangan segi fisik puzzle huruf latin yang pertama yaitu Berdasarkan wawanca validator ahli I dan II mengenai uraian indikator satu yaitu jenis bahan kayu yang akan digunakan adalah jenis bahan dari kayu seru memberikan 4 poin (Sangat valid). Validator I dan II memiliki pendapat yang sama mengenai hal tersebut yaitu, "karena pada umummnya mainan yang terbuat dari kayu kebanyakan menggunakan kayu seru, disisi lain kayu seru berbahan ringan, harga ekonomis, dan dapat digunakan dalam jangka waktu yang panjang. Adapun saran dari validator untuk memaksimalkan bahan cat yang akan digunakan agar aman untuk anak-anak".

Tanggapan validator I dan Validator II terhadap uraian indikator nomor dua dan nomor tiga yaitu ukuran sisi puzzle $40 \mathrm{~cm}$ x $32 \mathrm{~cm}$ dan ukuran kepingan puzzle $5 \mathrm{~cm}$ $x$ 5cm. Validator I dan II memberi poin 4 (Sangat valid) adapun alasan ke dua validator yaitu "pada umumnya ukuran permaianan terutama puzzle sudah standar, tidak terlalu besar dan tidak terlalu kecil untuk bisa dimainkan anak usia diatas 3 tahun dikecualikan untuk usia di bawah 3 tahun perlu dikombinasiakan ukurannya lebih besar lagi".

Tanggapan validator I dan validator II terhadap uraian indikator nomor empat yaitu bentuk kepingan puzzle bergelombang. Validator I memberi poin 3 (Valid) dan tidak mempermasalahkan bentuk kepingan puzzle, sedangkan untuk validator II memberi poin 2 (Kurang valid) dengan alasan masih kurang berinovasi dengan model yang telah peneliti buat.

Tanggapan validator I dan validator II terhadap uraian indikator nomor lima yaitu terdapat huruf latin besar dan kecil a-z. Validator I memberi poin 4 (Sangat valid) dengan alasan agar anak tidak kebingungan dalam mengenali huruf, sedikit koreksi dari validator I untuk tidak menempatkan posisi huruf besar dan huruf kecil secara berdekatan. sedangkan validator II memberi poin 3 (Valid) dengan alasan "untuk model puzzle realnya sudah bagus jika terdapat huruf besar dan huruf kecil, agar anak memahami persamaan dan perbedaanya. Sidikit saran dari validator II buat peneliti agar peletakannya direvisi kembali agar lebih bervariasi".

Tanggapan validator I dan Validator II terhadap uraian indikator nomor enam dan nomor tujuh yaitu terdapat macam-macam gambar dan nama gambar pada setiap kepingan puzzle huruf latin. Validator I dan II sama-sama memberi poin 4 (Sangat valid) dengan alasan yang hampir sama yaitu "karena mainan anak pada umummya harus bervariasi terutama dengan puzzle, yang harus memiliki kesesuaian gambar, nama gambar yang ingin diperkenalkan oleh anak, dan pemilihan gambar yang benar-benar harus diperhatikan peneliti. Adapun gambar 
yang dimaksud yaitu gambar yang sering dilihat, dikenali, dan gambar yang ada dalam kehidupan sehari-hari. Sehingga dapat membantu anak dalam proses pemahamannya, atau dapat tertanam dalam memori anak jadi ketika telah melihat gambar, secara tidak langsung anak dapat mengetahui penulisan nama gambar".

Tanggapan validator I dan validator II dengan uraian indikator nomor delapan yaitu kesesuaian gambar dengan huruf latin. Validator I dan II memberi poin 4 (Sangat valid) dengan alasan "agar dapat memberi kemudahan pada anak untuk mengenali bentuk, bunyi, dan tulisan. karena jika ada gambar dan hurufnya tidak sesuai (contoh: huruf $A=$ Sapi) maka dapat membuat anak kebingungan, oleh karena itu peneliti menyesuaikan huruf dan gambar (contoh: huruf $A=$ Ayam) jadi secara tidak langsung dapat melatih daya ingat dan kosa kata pada anak".

Tanggapan validator I dan validator II dengan uraian indikator nomor Sembilan yaitu terdapat macam-macam warna pada huruf, gambar, dan nama gambar. Validator I dan II memberi poin 4 (Sangat valid) dengan alasan "karena penggunaan warna pada sebuah media atau permainan sangat penting dan dapat menarik perhatian anak, meskipun yang paling utama dalam penelitian ini adalah pengenalan huruf latin tetapi secara tidak langsung anak juga sedang belajar pengenalan warna. Adapun saran dari validator II yaitu sebaiknya dalam penggunaan warna menggunakan warna yang terang atau cerah karena jika penggunaan warna gelap akan memungkinkan cepat pudar.

Tanggapan validator I dan validator II dengan uraian indikator nomor sepuluh dan sebelas yaitu jenis puzzle huruf latin jika dilihat dari kepraktisan, keawetan, dan ketahanan mudah disimpan, dipindahkan, dan aman jika menggunakan dari bahan kayu seru untuk anak usia dini. Validator I dan II memberi poin 4 (Sangat valid) dengan alasan "dapat memudahkan anak ketika memegang, mencabut dan memasang kepingan puzzle karena dapat memudahkan anak dalam penggunan media puzzle sebagai media pembelajaran dilihat dari kepraktisannya mudah untuk diangkat dan dipindahkan. Selain itu keawetan media bisa disimpan untuk jangka waktu yang lama".

\section{KESIMPULAN}

Berdasarkan hasil penelitian yang dilakukan peneliti maka dapat disimpulkan bahwa media puzzle huruf latin setelah dikembangkan sampai uji tahap validasi oleh ahli validator media untuk menumbuhkan kemampuan mengenal huruf latin anak usia dini, dapat dikatakn sangat valid untuk dipergunakan sebagai media pembelajaran huruf latin. Hal ini dikarenakan tidak terlepas dari keunggulankeunggulan yang terdapat pada media puzzle, sperti tema atau desain yang dapat menarik perhatian anak, ilustrasi yang berkaitan dengan huruf latin a-z, gambar dan nama gambar yang dapat melatih kosa kata pada anak sehingga anak lebih banyak menemukan perbendaharaan kata baru dan belajar kata secara kongkret. Selain itu media puzzle berperan dalam membangun minat baca pada anak dan memiliki 
metode penggunaan yang menarik, menyenangkan dan dapat dijadikan sebagai permainan yang memiliki manfaat untuk aspek perkembangan pada anak usia dini.

\section{DAFTAR PUSTAKA}

Cahyono, Hadi, 'Pola Pengembangan Pendidikan Karakter Siswa, Universitas Muhammadiyah Ponorogo', Jurnal Dimensi Pendidikan Dan Pembelajaran, 3.2 (2015)

Dinar, Sri Putri, 'Pengembangan Lembar Kerja Peserta Didik (LKPD) Berbasis Model Pembelajaran Diskursus Multi Reppresentasi (DMR) PadaMateri Sistem Reproduksi Manusia' (Universitas Islam Negri Alauddin Makassar, 2021)

Dwi, Estri martianingtyas, 'Research and Development: Inovasi Produk Dalam Pembelajaran, Researchgate' (Universitas Muhammadiah Purwokarto, 2019)

Khuriah, Marfuatun, 'Upaya Meningkatkan Kemampuan Berbahasa Anak Melalui Metode Bercerita Adi RA Muslimat NU Pasuruhan 2 Mertoyudan Magelang' (Fakultas Ilmu Tarbiyah dan Keguruan, Universitas Islam Negeri Sunan Kalijaga Yogyakarta, 2014)

Latif, Mukhtar. Zulkhairina, Rita Zubaidah, Muhammad Afandi, Orientasi Baru Pendidikan Anak Usia Dini (Jakarta: Kencana, 2016)

Madyawati, Lilis, Strategi Pengembangan Bahasa Pada Anak (Jakarta: kencana, 2017)

Marlinda Dona, 'Upaya Meningkatkan Kemampuan Mengenal Huruf Melalui Media Pohon Huruf (Penelitian Tindakan Kelas Pada Kelompok A Di TK Mafhadhol Tambang Sawah Kabupaten Lebong Provinsi Bengkulu)' (Bengkulu, Fakultas Keguruan Dan IImu Pendidikan, Universitas Bengkulu., 2014)

Mustami, Muhammad Khalifa, 'Validitas Pengembangan Penuntun Praktikum Ilustratif Mikroteknik Hewan Berbasis Guided Inquiry', Jurnal IImiah Pena, 11.1 (2017)

Punaji, Metode Penelitian Pendidikan Dan Pengembangan Edisi Ke Empat (Jakarta: PT Kharisma putra utama, 2016)

Putra Nusa, Research \& Development Penelitian Dan Pengembangan: Suatu Pengantar (Depok: PT Rajagrafindo Persada, 2019)

Rahayuningsih, Sheila Septiana. Tritjahjo Danny Soesilo, dan Mozes Kurniawan., 'Peningkatan Kemampuan Mengenal Huruf Pada Anak Usia 5-6 Tahun Melalui Metode Bermain Dengan Media Kotak Pintar', Jurnal Pendidikan an Kebudayaan, 9.1 (2019)

64 NANAEKE - Indonesian Journal of Early Childhood Education, Vol. 4, No. 1, Juni 2021 
Sari, Yeni Diana Mella, 'Pengembangan Media Puzzle Berbasis Make A Match Materi Pengambilan Keputusan Bersama Untuk Meningkatkan Hasil Belajar PKN Kelas VA SDN Bojong Salaman 01 Samarang' (Fakultas IImu Pendidikan, Universitas Negeri Samarang, 2016)

Srimulyanti, 'Pengembangan Puzzle Edukatif Sebagai Media Pengenalan Angka Ntuk Kelompok A Di TK Purbonegaran, Gondokusuman, Yogyakarta' (Yogyakarta, Fakultas IImu Pendidikan, Universitas Negri Yogyakarta, 2016)

Sugiyono, Metode Penelitian Kuantitatif Kualitatif Dan R\&D (Bandung: Alfabeta, 2019)

Trisniwati, 'Peningkatan Kemampuan Mengenal Huruf Melalui Metode Permainan Kartu Huruf Pada Kelompok B1 TK ABA Ketanggungan Wirobrajan Yogyakarta' (Fakultas IImu Pendidikan, Universitas Negri Yogyakarta, 2014) 